\title{
Microfluidization of dairy model emulsions. I. Preparation of emulsions and influence of processing and formulation on the size distribution of milk fat globules
}

\author{
O Robin, V Blanchot, JC Vuillemard, P Paquin
}

Université Laval, Sainte-Foy, centre de recherche en sciences et technologies du lait (STELA), département de sciences et technologie des aliments, (Québec), Canada G1K7P4

(Received 1st July 1992; accepted 17 September 1992)

\begin{abstract}
Summary - The influence of certain process variables (pressure and temperature) as well as composition variables (fat, protein and low molecular weight emulsifier concentrations) on the size distribution of milk fat globules was studied in a dairy model emulsion (oil-in-water) produced by microfluidization, a mechanical emulsification technique. The use of a central composite experimental design allowed us to obtain 2 nonlinear multiple regression equations relating the volume-weighted average diameter of the fat globules $\left(\overline{d_{v}}\right)$ as well as the relative size distribution width $(\mathrm{cv})$ to the emulsification pressure $(7.8-76.3 \mathrm{MPa})$ and temperature $\left(35-100{ }^{\circ} \mathrm{C}\right)$, and to sodium caseinate $(0.5-3.9 w t \%)$, butter oil (5.2-14.7 wt\%) and monoglyceride $(0.08-0.88 w t \%)$ concentrations. These 2 functions account respectively for 93.7 and $81.7 \%$ of the variation in the average diameter and in the size distribution width of the microfluidized fat globules and were used to explain certain interactions between the different variables affecting the size of the microfluidized fat globules. They were also used to demonstrate the existence of the optimal conditions that correspond to the extremes of the average particle diameter and of the distribution width of the fat globules. Finally, these 2 functions allowed us to predict fat globule size parameters as a function of process and formulation conditions.
\end{abstract}

emulsification / microfluidization / oil-in-water emulsion / fat globule

Résumé - Microfluidisation d'émulsions laitières modèles. I. Préparation des émulsions et influence des facteurs de procédé et de formulation sur la distribution de la taille des globules de gras. L'influence de certaines variables opératoires (pression et température) et des variables de composition (teneurs en huile de beurre, en protéine et en émulsifiant de faible poids mo-

Symbols used and SI units: $[B O]=$ butter oil concentration $(w t \%) ; c v=$ coefficient of variation or relative standard deviation of the volume-weighted size distribution $(\%) ; \bar{d}_{v}=$ volume-weighted average fat globule diameter $(\mathrm{m}) ; \mathrm{D}=$ diffusion coefficient $\left(\mathrm{m}^{2} \cdot \mathrm{s}^{-1}\right) ; F=$ number of factorial points of the design and Fisher ratio; $k=$ number of independent variables or conductivity of a solution $\left(S \cdot \mathrm{m}^{-1}=\right.$ $\left.\mathrm{m}^{-3} \cdot \mathrm{kg}^{-1} \cdot \mathrm{s}^{3} \cdot \mathrm{A}^{2}\right) ;[M G S]=$ monoglyceride concentration $(w t \%) ;[$ Prof $]=$ protein concentration $(w t \%) ;$ $P=$ emulsification pressure $\left(\mathrm{Pa}=\mathrm{m}^{-1} \cdot \mathrm{kg} \cdot \mathrm{s}^{-2}\right) ; Q=$ flow rate $\left(\mathrm{m}^{3} \cdot \mathrm{s}^{-1}\right) ; S=$ interfacial area $\left(\mathrm{m}^{2}\right) ; T=$ emulsification temperature (K); $\alpha=$ distance separating a star point from a factorial point in terms of coded variables (dimensionless); $\varepsilon=$ power density $\left(\mathrm{W} \cdot \mathrm{m}^{-3}=\mathrm{m}^{-1} \cdot \mathrm{kg} \cdot \mathrm{s}^{-3}\right) ; \Phi=$ volume fraction of the disperse phase (dimensionless); $\gamma=$ interfacial tension $\left(\mathrm{N} \cdot \mathrm{m}^{-1}=\mathrm{kg} \cdot \mathrm{s}^{-2}\right) ; \rho=$ mass density $\left(\mathrm{kg} \cdot \mathrm{m}^{-3}\right)$. 
léculaire) sur la distribution de la taille des globules de gras d'une émulsion laitière modèle (huile dans l'eau) a été étudiée pour une technologie d'émulsification mécanique donnée : la microfluidisation. L'utilisation d'un dispositif expérimental central composite a permis l'obtention de 2 équations de régression multiple non linéaires reliant le diamètre moyen des globules de gras $\left(\bar{d}_{\mathrm{v}}\right)$ ainsi que l'étendue relative de la dispersion des tailles (cv) à la pression $(7,8-76,3 \mathrm{MPa})$ et à la température d'émulsification $\left(35-100^{\circ} \mathrm{C}\right)$, aux teneurs en caséinate de sodium $(0,5-3,9 \%$ de la masse totale), en huile de beurre $(5,2-14,7 \%)$ et en monoglycéride $(0,08-0,88 \%)$. Ces 2 fonctions expliquent respectivement $93,7 \%$ et $81,7 \%$ des variations du diamètre moyen des globules de gras microfluidisés et de l'étendue relative de la distribution des tailles dans les valeurs considérées des paramètres. Ces fonctions ont en outre permis d'expliquer certaines interactions entre les différentes variables précitées sur la distribution de la taille des globules de gras microfluidisés. Elles ont également permis de mettre en évidence l'existence de conditions optimales correspondant à des extremums du diamètre particulaire moyen et de l'étendue de la distribution de la taille des globules de gras. Finalement, ces 2 fonctions nous ont permis de prédire la distribution de la taille des globules de gras en fonction des conditions de procédés et de formulation.

\section{émulsification / microfluidisation /émulsions huile dans l'eau / globules de gras}

\section{INTRODUCTION}

For a number of industries, the homogenization, and more generally the mechanical emulsification of liquids, dietary as well as others, has become over the past many years an important technological process. The use of this type of process in the food, pharmaceutical and cosmetic industries in general and in certain dairy operations in particular is essential for the production of emulsions with certain desirable rheological properties (creams and ointments), textures (ice cream, mayonnaise) and degrees of stability (milk, salad dressing) (Dickinson and Stainsby, 1988). The principle of homogenization and mechanical emulsification processes which, according to Gaulin, must allow "de fixer la composition des liquides" remains simple: in the case of milk, the homogenization process results in a considerable decrease in the size of the fat globules found in the initial suspension, and has the effect of increasing the creaming stability of the emulsion (Tadros and Vincent, 1983). Aside from conventional homogenizers, relatively few mechanical emulsification processes have been and are used in an industrial setting
(Walstra, 1983). During the 1980s, however, other mechanical emulsification processes appeared. One of them, called microfluidization (Cook and Lagace, 1985; Washington, 1987), was initially used principally in the cosmetic and pharmaceutical industries (Chandonnet et al, 1985). More recently, microfluidization was suggested as an alternative method for the production of milk fat microcapsules (Vuillemard, 1991), alcoholized creams (Paquin and Giasson, 1989) and for milk homogenization (Pouliot et al, 1991). If the result of the process is similar to that of homogenization (reduction in the size of the fat globules), the means used to achieve such a result are different. As is the case for conventional homogenization processes, the liquid is forced under high pressure into a chamber. However, in the case of the microfluidization process, the liquid is then divided into 2 microstreams that are projected against one another at high speed and at an angle of $180^{\circ}$ (Cook and Lagace, 1985).

Other than a considerable change in the dispersion state of the fat, the emulsification of dietary liquids also results in a considerable rearrangement of the oil-water interface 
(Walstra and Oortwijn, 1982) where mainly 2 classes of molecules can be adsorbed: amphiphilic macromolecules (mainly proteins) and low molecular weight emulsifiers (lecithins, monoglycerides, Tweens, Spans, etc) (Dickinson et al, 1990). Proteins and low molecular weight emulsifiers affect the production and stabilization of emulsions. Proteins play 2 major roles: on the one hand they lower surface tension between the interfaces that are formed during the emulsification process, and on the other hand, they form a macromolecular layer surrounding the dispersed particles which structurally stabilizes the emulsion by reducing the rate of recoalescence (Fisher and Parker, 1988). Low molecular weight emulsifiers affect the production and stabilization of emulsions in several ways: during emulsification, by reducing interfacial tension more rapidly than would the proteins alone, they allow the production of smaller-sized dispersed particles (Darling and Birkett, 1987). Furthermore, while proteins generally stabilize oil-in-water emulsions, low molecular weight emulsifiers tend to destabilize them (Dickinson et al, 1990) by removing protein from the surface of the dispersed particles. This ability of low molecular weight emulsifiers to dislodge macromolecules is due to their greater energy of adsorption compared to individual segments of macromolecules. Finally, if the distribution of these 2 classes of molecules between the surfaces of the dispersed particles and the bulk phase is directly affected by the competitive adsorption between the macromolecules and the emulsifiers at the oil-water interface, it is also a result of the nature of macromoleculeemulsifier interactions at the interface and in the bulk phase (Dickinson, 1986).

Opinions are divided as to the usefulness of using experimental model systems (systems containing a single protein source and/or low molecular weight emulsifier) rather than real food systems (Darling and Birkett, 1987; Dickinson et al, 1990). Even if the model systems allow relatively precise information to be obtained, they can rarely be extrapolated to real food systems. An alternative would be to use systems that can be called "quasi-foods", that is systems that contain a known mixture of proteins and low molecular weight surfactants and whose concentrations are controlled.

The aim of the study presented here was to examine the influence of certain process (pressure and temperature) and composition (butter oil, protein and surfactant concentrations) variables on the size distribution of fat globules in a model dairy emulsion (oil-in-water) using a given mechanical emulsification technology, ie microfluidization.

\section{MATERIALS AND METHODS}

\section{Experimental design}

\section{Description}

A central composite rotatable design made up of $k=5$ factors with 3 levels and 1 repetition was developed. This type of design, the most widely used for fitting experimental results to a secondorder model (Piggot, 1986; Box and Drapper, 1987 ), is called rotatable because the variance of the estimated response $\hat{y}$ at point $x$ is uniquely a function of the distance separating this point from the centre point and not of the direction. These designs are composed of $2^{k}$ factorial points (usually coded \pm 1 ) with $2^{k}$ star points coded $[( \pm \alpha, 0,0, \ldots, 0),(0, \pm \alpha, 0, \ldots, 0), \ldots,(0$, $0,0, \ldots \pm \pm \alpha)]$ and $n_{0}$ centre points coded $(0,0$, ..., 0 ). The value of $\alpha$, on which the rotability of the design depends, is such that $\alpha=(F)^{1 / 4}$ where $F$ is the number of factorial points of the design: in the present case $F=2^{k}$. The complex principles for the development of these designs have been presented by various authors including Montgomery (1976), Gacula and Singh (1984), and Box and Drapper (1987).

The design used was therefore composed of $2^{5}$ factorial points, with 10 star points (with $\alpha=$ 
2.38) and 10 centre points which results in a total of 52 experimental units or emulsions.

The 5 factors that were varied in the preparation of the emulsions are the following: 2 process factors-emulsification pressure $(7.8,20.7$, $41.4,62.1$ and $76.3 \mathrm{MPa})$ and temperature (35, $55,70,85$ and $100{ }^{\circ} \mathrm{C}$ ), and 3 formulation factors-protein concentration $(0.5,0.9,1.5,2.5$ and $3.9 \mathrm{wt} \%)$, butter oil concentration $(5.2,8,10,12$ and $14.8 w t \%)$ and monoglyceride concentration $(0.08,0.2,0.4,0.6$ and $0.88 w t \%)$.

\section{Statistical analysis}

An analysis of variance was first conducted on the values of the volume-weighted average diameters of the emulsified fat globules $\left(\bar{d}_{v}\right)$ and on the relative width (cv) of the particle size distribution. This analysis allowed the split of the total variation of the measured parameters $\left(\bar{d}_{v}\right.$ and $c v$ ) according to the principal effects of the treatments, the interactions and the error. The sum of the squares of the differences of the principal effects was split in unitary degree of freedom using an orthogonal comparison method (Box and Drapper, 1987). This calculation allowed an individual estimation of effects without mutual interference. Two tests were then carried out: a Fisher test allowed a differentiation between the treatments and the interactions which had a significant effect on a given parameter, and an adjustment test (Neter et al, 1985) confirmed that the second-order model allowed an adequate description (to \pm $1 \%$ ) of the variances in the experimental results.

The effects of the principal treatments and/or interactions which were not significant at the level $95 \%$ have been included in the error term. This pooling, which has been justified by Little (1981), increases the degree of significance of the variance due to an increase in the number of degrees of freedom. Although a lower probability threshold could be used in the selection of the effects to be considered in the determination of the regression equation, a probability threshold of at least $95 \%$ was used in order to simplify the expression and use of the regression equations.

Finally, following this second analysis of variance, each of the 2 measured parameters $\left(\vec{d}_{v}\right.$ and $\mathrm{cv}$ ) was analyzed as a function of the principal effects and interactions of process and composition variables. The nullity of the regression coefficients was tested using Student's test (Neter et al, 1985).

This method for interpreting results is supported and recommended by Little (1981) and Box and Drapper (1987). According to these authors, all the treatment levels in the experimental range are significantly different in their effects after a significant tendency has been established. The best estimates of the effects of the treatments are those values calculated using the regression equation.

\section{Statistical procedure and graphic}

The analysis of variance and regression calculations were carried out using the General Linear Model procedure (Proc GLM and Proc REG) of the SAS (1990).

The 3-dimensional picture of the equations was carried out using Mathematica (Wolfram, 1991).

\section{Emulsion preparation}

\section{Ingredients}

Sodium caseinates $(89.3 \%$ protein) were obtained from ICN Nutritional Biochemicals, Canada Ltd (Dorval, Que, Canada). Butter oil ( $99.4 \%$ anhydrous) was purchased from a local dairy cooperative (Agropur, Granby, Quebec, Canada) and was stored at $4{ }^{\circ} \mathrm{C}$. Distilled monoglycerides (EXCEL, T-95) with a hydrophile-lipophile balance (HLB) of 4.5 (Shinoda and Kunieda, 1983) were purchased from Atkemix (Bratford, Ontario, Canada). Sodium azide was purchased from Fisher Scientific (Quebec, Que, Canada).

\section{Emulsion production}

Fifty-two emulsions $(600 \mathrm{~g})$ containing $0.5,0.9$, $1.5,2.5$ or $3.9 \mathrm{wt} \%$ (based on protein content) sodium caseinates, $5.2,8,10,12$ or $14.8 \mathrm{wt} \%$ butter oil, and $0.08,0.2,0.4,0.6$ or $0.88 \mathrm{wt} \%$ monoglyceride were prepared in the following manner: various sodium caseinate solutions, hydrated and solubilized in deionized water $\left(k=1.1 \mu \mathrm{S} . \mathrm{cm}^{-1}\right)$ for $90 \mathrm{~min}$, and butter oil, preheated to $50^{\circ} \mathrm{C}$, were mixed using a magnetic stirrer. The solutions were then brought to the appropriate emul- 
Table I. Process variables (protein, butter oil and monoglyceride concentrations, emulsification pressure and temperature) and responses of the central composite rotatable design in terms of volume-weighted average diameter and relative width of the emulsified fat globules distribution.

Variables de procédés (concentrations en protéine, huile de beurre et monoglycéride, pression et température d'émulsification) et réponses en termes du diamètre pondéré en volume et du coefficient de variation de la distribution de la taille des globules de gras émulsifiés.

Trials [Prot] [BO] [MGS] $\mathrm{P} \quad \mathrm{T} \quad\left(\overline{\mathrm{d}}_{\mathrm{v}}\right) \mathrm{cv}$ (wt\%) (wt\%) (wt\%) (MPa) $\left({ }^{\circ} \mathrm{C}\right)(\mathrm{nm})(\%)$

\begin{tabular}{|c|c|c|c|c|c|c|}
\hline \multicolumn{7}{|c|}{ Factorial points } \\
\hline 1 & 0.5 & 8 & 0.2 & 20.7 & 55 & 584 \\
\hline 2 & 0.5 & 8 & 0.2 & 20.7 & 85 & 594 \\
\hline 3 & 0.5 & 8 & 0.2 & 62.1 & 55 & 480 \\
\hline 4 & 0.5 & 8 & 0.2 & 62.1 & 85 & 466 \\
\hline 5 & 0.5 & 8 & 0.6 & 20.7 & 55 & 427 \\
\hline 6 & 0.5 & 8 & 0.6 & 20.7 & 85 & 382 \\
\hline 7 & 0.5 & 8 & 0.6 & 62.1 & 55 & 317 \\
\hline 8 & 0.5 & 8 & 0.6 & 62.1 & 85 & 326 \\
\hline 9 & 0.5 & 12 & 0.2 & 20.7 & 55 & 806 \\
\hline 10 & 0.5 & 12 & 0.2 & 20.7 & 85 & 793 \\
\hline 11 & 0.5 & 12 & 0.2 & 62.1 & 55 & 808 \\
\hline 12 & 0.5 & 12 & 0.2 & 62.1 & 85 & 777 \\
\hline 13 & 0.5 & & 0.6 & 20.7 & 55 & 460 \\
\hline 14 & 0.5 & 12 & 0.6 & 20.7 & 85 & 491 \\
\hline 15 & 0.5 & 12 & 0.6 & 62.1 & 55 & 407 \\
\hline 16 & 0.5 & 12 & 0.6 & 62.1 & 85 & 419 \\
\hline 17 & 2.5 & 8 & 0.2 & 20.7 & 55 & 509 \\
\hline 18 & 2.5 & 8 & 0.2 & 20.7 & 85 & 482 \\
\hline 19 & 2.5 & & 0.2 & 62.1 & 55 & 439 \\
\hline 20 & 2. & 8 & 0.2 & 62.1 & 85 & 358 \\
\hline 21 & 2.5 & 8 & 0.6 & 20.7 & 55 & 423 \\
\hline
\end{tabular}

sification temperature $\left(35,55,70,85\right.$ or $\left.100{ }^{\circ} \mathrm{C}\right)$ and the emulsifiers were added. The dispersions, maintained at the emulsification temperature $( \pm$ $1.5^{\circ} \mathrm{C}$ ), were then mixed for 2 min using a stirrer (Braun CDN Ltd, Model MR7, Mississauga, Ont, Canada). The oil-in-water dispersions were then immediately emulsified using a Microfluidizer (M$110^{\mathrm{TM}}$, Microfluidic Corporation, Boston, MA, USA) at its maximum power setting.

$\begin{array}{rrrrrrrr}22 & 2.5 & 8 & 0.6 & 20.7 & 85 & 407 & 47 \\ 23 & 2.5 & 8 & 0.6 & 62.1 & 55 & 361 & 46 \\ 24 & 2.5 & 8 & 0.6 & 62.1 & 85 & 300 & 51 \\ 25 & 2.5 & 12 & 0.2 & 20.7 & 55 & 574 & 56 \\ 26 & 2.5 & 12 & 0.2 & 20.7 & 85 & 593 & 59 \\ 27 & 2.5 & 12 & 0.2 & 62.1 & 55 & 538 & 52 \\ 28 & 2.5 & 12 & 0.2 & 62.1 & 85 & 539 & 40 \\ 29 & 2.5 & 12 & 0.6 & 20.7 & 55 & 609 & 45 \\ 30 & 2.5 & 12 & 0.6 & 20.7 & 85 & 653 & 46 \\ 31 & 2.5 & 12 & 0.6 & 62.1 & 55 & 563 & 28 \\ 32 & 2.5 & 12 & 0.6 & 62.1 & 85 & 509 & 32\end{array}$

Centre points

$\begin{array}{llllllll}33 & 1.5 & 10 & 0.4 & 41.4 & 70 & 420 & 46 \\ 34 & 1.5 & 10 & 0.4 & 41.4 & 70 & 427 & 45 \\ 35 & 1.5 & 10 & 0.4 & 41.4 & 70 & 451 & 45 \\ 36 & 1.5 & 10 & 0.4 & 41.4 & 70 & 448 & 45 \\ 37 & 1.5 & 10 & 0.4 & 41.4 & 70 & 415 & 46 \\ 38 & 1.5 & 10 & 0.4 & 41.4 & 70 & 441 & 46 \\ 39 & 1.5 & 10 & 0.4 & 41.4 & 70 & 465 & 43 \\ 40 & 1.5 & 10 & 0.4 & 41.4 & 70 & 433 & 45 \\ 41 & 1.5 & 10 & 0.4 & 41.4 & 70 & 471 & 41 \\ 42 & 1.5 & 10 & 0.4 & 41.4 & 70 & 444 & 46\end{array}$

Star points

$\begin{array}{cccccccc}43 & 0.9 & 10 & 0.4 & 41.1 & 70 & 442 & 50 \\ 44 & 3.9 & 10 & 0.4 & 41.4 & 70 & 403 & 29 \\ 45 & 1.5 & 5.2 & 0.4 & 41.4 & 70 & 291 & 31 \\ 46 & 1.5 & 14.8 & 0.4 & 41.4 & 70 & 633 & 52 \\ 47 & 1.5 & 8 & 0.08 & 41.4 & 70 & 549 & 53 \\ 48 & 1.5 & 8 & 0.88 & 41.4 & 70 & 324 & 30 \\ 49 & 1.5 & 8 & 0.4 & 7.8 & 70 & 942 & 39 \\ 50 & 1.5 & 8 & 0.4 & 76.3^{1} & 70 & 461 & 66 \\ 51 & 1.5 & 8 & 0.4 & 41.1 & 35^{2} & 655 & 55 \\ 52 & 1.5 & 8 & 0.4 & 41.4 & 100^{3} & 513 & 58\end{array}$

For the design rotability to be perfect $(\alpha=2.378$ ), the values of some independent parameters should be: ${ }^{1}$ emulsion $50, P=90.6 \mathrm{MPa}$ (in fact, the maximum pressure given by the air feed system was $76.5 \mathrm{MPa}) ;{ }^{2}$ Emulsion 51, $T=34.3^{\circ} \mathrm{C} ;{ }^{3}$ Emulsion $52, T=105.7^{\circ} \mathrm{C}$.

The microfluidization procedure was performed in 2 stages: the first processing was at $7.8,20.7,41.4,62.1$ or $76.3 \mathrm{MPa}$ and the second at $4.8 \mathrm{MPa}$ in order to eliminate aggregates formed during the first processing procedure (Ogden, 1973; Walstra, 1975). The composition of the emulsions is given in table I.

Sodium azide, an antibacterial agent, was added to each emulsion $(0.2 \% \mathrm{vol} / \mathrm{wt})$, and $2 \mathrm{pH}$ 
measurements ( $\mathrm{pH}$-meter, Corning 140 , electrode 476530, Canlab, Montreal, Que, Canada) were carried out.

\section{Size distribution of the emulsified fat globules}

\section{Sampling}

A sample of each emulsion was taken and stored at $4{ }^{\circ} \mathrm{C}$ for $24 \mathrm{~h}$ in a $20 \mathrm{ml}$ bottle completely filled. Before analysis, the samples were heated $\left(T=20^{\circ} \mathrm{C}\right)$ and manually stirred. This procedure, proposed by Walstra (1975), was used in order to prevent a change in the size distribution of the fat globules due to churning.

\section{Dissociation of protein structures}

The samples were mixed with a buffer (urea, EDTA and $\beta$-mercaptoethanol, $\mathrm{pH}$ 7) designed by Dalgleish et al (1987) to dissociate protein structures. Despite the presence of sodium caseinates in the emulsions, the composition of the dissociating buffer was not modified. Measurements were carried out immediately after vigorous manual stirring.

\section{Photon correlation spectrophotometry}

The size distributions of the fat globules were determined by photon correlation spectrometry (PCS) using the method proposed by Robin and Paquin (1991). The measurements were taken using the Nicomp multibit ( 7 bit) 64-channel photon correlation system (Pacific Scientific, Hiac/Royce Instruments Division, Model 370, Manlo Park, CA, USA); the correlation functions were measured on the light that was diffused at an angle of $90^{\circ}$ by the particles in suspension. The correlation functions were analyzed by the cumulants method (Koppel, 1972). The first cumulant yielded an average diffusion coefficient (D), and the second yielded a mean squared deviation of the average diffusion coefficient $\left(s^{2}\right)$. The volume-weighted average particle diameters $\left(\overline{d_{v}}\right)$ were calculated using the StokesEinstein law, and polydispersity was expressed by the relative standard deviation or coefficient of variation $(\mathrm{Cv})$ of the volume-weighted distribution calculated as the distribution width divided by the average diameter. The accuracy $(\cong 1 \%)$, the reproducibility $(\equiv 1 \%)$ as well as the length of the analysis $\left(2.5 \times 10^{6}\right.$ photo-impulses or $\approx 20$ $\mathrm{min}$ ) were determined on latex sphere solutions (Robin and Paquin, 1991).

Three measurements of the size distribution of the fat globules were carried out on each sample. The values of the average diameters and relative widths of the size distribution of the fat globules are shown in table $I$.

\section{Average size distributions}

A logarithmic transformation was applied to the emulsified fat globule volume-weighted average diameter $\left(\overline{d_{v}}\right)$ and to the homogenization pressure. Indeed, using the theory of isotropic turbulence developed by Kolmogorov (Walstra, 1969, 1983) showed that the maximum size of a fat globule undergoing the homogenization process is a function of the energy density $\varepsilon$ (energy dissipated per unit of volume and time) or of the pressure $P\left(\varepsilon \propto P^{B / 2} \rho^{-1 / 2}\right)$, of the interfacial tension $\gamma$, and of the mass density $\rho$ according to:

$$
\begin{gathered}
d_{\max } \propto\left(\varepsilon^{-2} \gamma^{3} \rho^{-1}\right) \frac{1}{5} \propto P-\frac{3}{5} \\
\log _{10}\left(d_{\max }\right) \alpha-\frac{3}{5} \log _{10}(P)
\end{gathered}
$$$$
\text { or }
$$

Goulden and Phipps (1964), Walstra (1975) and others have experimentally confirmed these results.

\section{RESULTS}

\section{Accuracy and reproducibility of the PCS technique}

The 10 centre points serve as an indication of the reproducibility of the PCS technique for determining the parameters of the size distribution of the fat globules. These centre points correspond to values obtained from the same emulsion. Using these results, the reproducibility of the evaluation of the $\bar{d}_{v}$ and cV parameters was approximately 4.2 , and 
$3.2 \%$ respectively. However, even though the reproducibility of the results seem satisfying, that is, comparable with those obtained by other methods, their accuracy must be interpreted with some caution. Even though the validity of the PCS technique, in terms of precision and reproducibility, has been demonstrated by scattering from known mixtures of relatively monodispersed polystyrene latex beads (Bargeron, 1974; Brown and Pusey, 1975), results become less reliable when distributions are larger and polydispersed (Weiner and Tscharnuter, 1987). Moreover, if the second cumulant is generally dominated by polydispersity rather than by statistical noise in the autocorrelation function, in large distributions the analysis of the cumulant can lead to an underestimation of the variance (Chu and Dinapoli, 1983). Higher order terms should be taken into account, but this remains a difficult problem (Nicoli, personal communication).

\section{Influence of process variables on the average diameter of fat globules and on the distribution width of the diameters}

An analysis of variance was carried out on the values given in table I using orthogonal comparisons between the principal treatments and between the interactions (Box and Drapper, 1987). An F test was carried out to differentiate the treatments and the interactions which had a significant effect on the volume-weighted average diameter of the fat globules $\left(\bar{d}_{v}\right)$ and on the size distribution of the relative width (cv). An adjustment test of the experimental results for a second-order model was also carried out.

\section{Average diameter of the emulsified fat globules}

Table II shows the analysis of variance of the $\log _{10}\left(\bar{d}_{v}\right)$ as a function of process
Table II. Analysis of variance of the logarithm of the volume-weighted average fat globule diameter versus process and composition variables. Analyse de variance du logarithme du diamètre moyen pondéré en volume des globules de gras, en fonction des variables de procédé et de composition.

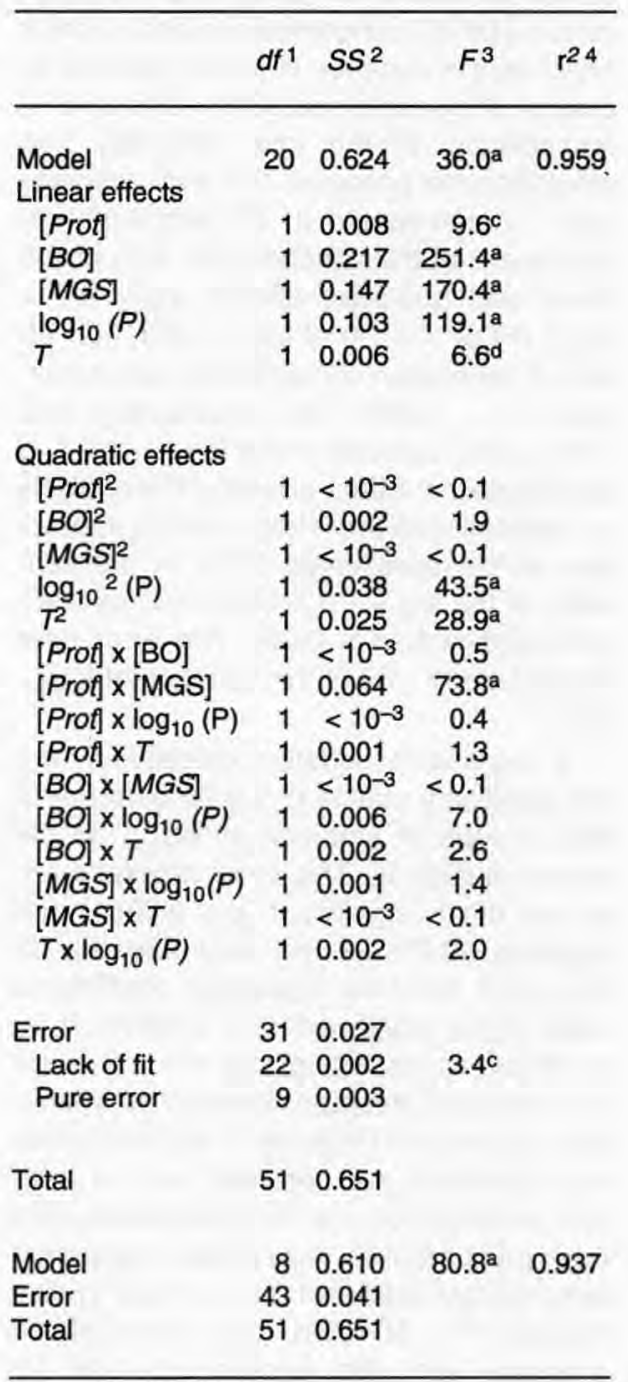

${ }^{1} \mathrm{df}=$ degree of freedom; ${ }^{2} \mathrm{SS}=$ sum of squares; ${ }^{3} \mathrm{~F}=$ Fisher ratio; ${ }^{4} r^{2}=$ coefficient of determination. Significance levels ${ }^{\mathrm{a}} p \leq 0.0001 ;{ }^{\mathrm{b}} p \leq 0.001 ;{ }^{\mathrm{c}} p \leq 0.01 ;{ }^{\mathrm{d}} p \leq$ 0.05 . 
variables. According to the adjustment test, for $p \leq 0.01$ ( $F<4.77$ ), the secondorder model allowed an adequate description of the variance of $\log _{10}\left(\bar{d}_{v}\right)$. Furthermore, the linear effects of all the principal factors were significant (from 95\% to $99.999 \%)$. Butter oil ([BO]) and monoglyceride ([MGS]) concentrations had a major effect on the variance of the fat globule diameter: they explained $33.4 \%$ and $22.6 \%$, respectively, of the total variance. The emulsification pressure $(P)$ and temperature $(T)$ represented $21.7 \%$ and $4.8 \%$ respectively, of the variance (the sum of the linear and quadratic effects: $\log _{10}(P)+$ $\log _{10}^{2}(P)$ or $\left.T+T^{2}\right)$ of $\left.\log _{10}\left(\bar{d}_{v}\right)\right)$. The effect of the protein concentration was significant $(p \leq 0.001)$ but represented only $1.3 \%$ of the variance of the $\log _{10}\left(\bar{d}_{v}\right)$. The last significant effect given by the analysis of variance was the [Prof] $x$ [MGS] interaction which represented $9.8 \%$ of the variance of the $\log _{10}\left(\bar{d}_{v}\right)$. Other effects were not significant $(p>0.05)$. The error term represented $\approx 4 \%$ of the variance of $\log _{10}$ $\left(\bar{d}_{v}\right)$.

A regression equation calculated from the significant effects ( $p \leq 0.05$ or more) of the analysis of variance of $\log _{10}\left(\bar{d}_{v}\right)$ is shown in table III. This second-order model was highly significant $(p \leq 0.0001)$ and explains $93.7 \%$ of the total variance of $\log _{10}\left(\bar{d}_{v}\right)$. All of the regression coefficients were highly significant ( $p \leq 0.0001)$. It is, however, worth noting that the existence of a minimum average diameter as a function of pressure (regression equation) was not significant, and resulted from an artefact produced by one of the extreme point (star point No 48). A separate regression analysis revealed that the increase in size beyond $P \cong 50 \mathrm{MPa}$ (the emulsification pressure from the regression model for which the derivative equals 0 ) was not significant.

Figure 1 is the response surface obtained from a second-order model relating
Table III. Analysis of regression and secondorder model of the logarithm of the volumeweighted average fat globule diameter versus significant variables and interactions.

Analyse de régression et modèle de second ordre du logarithme du diamètre moyen pondéré en volume des globules de gras émulsifiés, en fonction des variables et des interactions significatives.

\section{Estimate ${ }^{1} \quad S^{2} D^{2} \quad t^{3}$}

$\begin{array}{lrlr}\begin{array}{l}\text { Parameter: } \\ \text { Intercept }\end{array} & 14.293 & 1.6 & 9.1^{\mathrm{a}} \\ {[\text { Prof] }} & -0.102 & 1.210^{-2} & -8.5^{\mathrm{a}} \\ {[B O]} & 0.035 & 210^{-3} & 15.2^{\mathrm{a}} \\ {[\mathrm{MGS}]} & -0.633 & 510^{-2} & -13.4^{\mathrm{a}} \\ \log _{10}(P) & -4.755 & 0.7 & -6.9^{\mathrm{a}} \\ T & -0.016 & 310^{-3} & -5.5^{\mathrm{a}} \\ \log _{10}{ }^{2}(P) & 0.506 & 0.1 & 6.6^{\mathrm{a}} \\ T^{2} & 1.110^{-4} & 210^{-5} & 5.2^{\mathrm{a}} \\ {[\text { Prof }] \times[M G S]} & 0.223 & 2.710^{-2} & 8.2^{\mathrm{a}} \\ \log _{10}\left(\overline{d_{v}}\right)=14.293-0.102[\text { Prof }]+0.035[B O] \\ \quad-0.633[M G S]-4.755 \log _{10}(P) \\ -0.016 T+0.506 \log _{10}{ }^{2}(P) \\ +10^{-4} T^{2}+0.223[\text { Prof } \times \text { MGS }\end{array}$

Validity intervals:

$7800 \leq P \leq 76310 \mathrm{kPa} 0.5 \leq[\mathrm{Prot}] \leq 3.9 \mathrm{wt} \%$

$35 \leq T \leq 100^{\circ} \mathrm{C} \quad 5.2 \leq[B O] \leq 14.8 w t \%$

$0.08 \leq[M G S] \leq 0.88 w t \%$

${ }^{1}$ Estimate $=$ parameter estimated under the regression model (table II). ${ }^{2}$ STD = standard error of the estimate; ${ }^{3} t=$ value of Student's $t$-test. Significance level: a: $p \leq$ 0.0001 .

the values of $\bar{d}_{v}$ as a function of the butter oil concentration ([BO], wt\%) and of the emulsification pressure ( $\mathrm{P}, \mathrm{MPa})$ for a fixed temperature $\left(50^{\circ} \mathrm{C}\right)$ and for fixed protein $(1.5 w t \%)$ and monoglyceride $(0.4$ $w t \%)$ concentrations. As has been reported elsewhere, the average diameter of the fat globules decreases and reaches a plateau as emulsification pressure increases, 


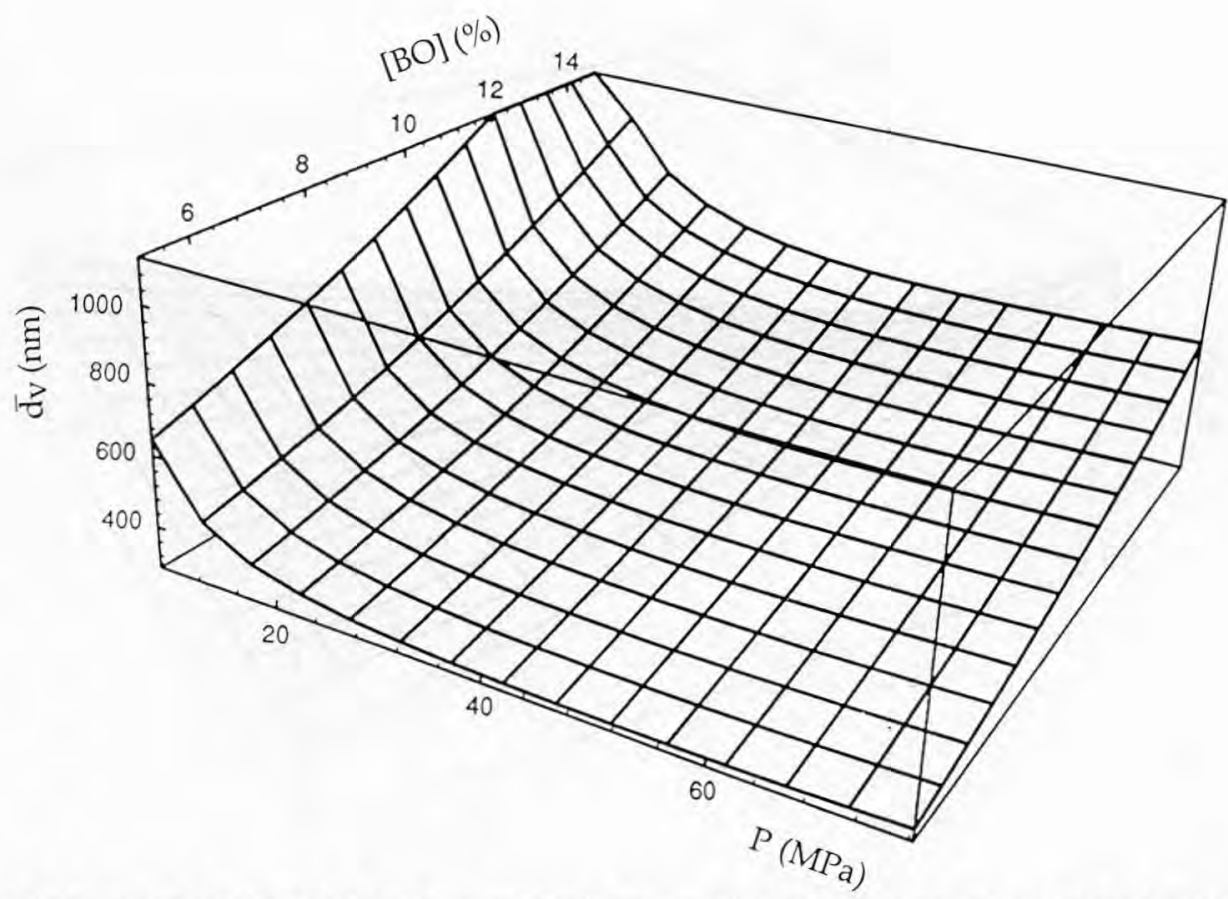

Fig 1. Response surface of the volume-weighted average fat globule diameter as a function of emulsification pressure, $P(\mathrm{MPa})$, and butter oil concentration, $[B O](\mathrm{wt} \%)$, for a fixed temperature $\left(T=50^{\circ} \mathrm{C}\right)$, a fixed protein concentration $([P r o f]=1.5 \mathrm{wt} \%$ ), and a fixed monoglyceride concentration $([M G S]=0.4$ wt\%).

Surface de réponse du diamètre moyen pondéré en volume des globules de gras en fonction de la pression d'émulsification, $\mathrm{P}(\mathrm{MPa})$, et de la concentration en huile de beurre, [BO] (\%), pour une température donnée $\mathrm{T}=50^{\circ} \mathrm{C}$ ), et des concentrations fixées en protéines ([Prot $]=1.5 \%$ et en monoglycérides ([MGS] $=0.4 \%$ ).

but increases as the fat content increases (Walstra, 1975; Phipps, 1985).

Figure 2 shows the complex influences of emulsifier type and concentration on fat globule size, for emulsions produced under conditions of constant pressure (50.0 $\mathrm{MPa})$, temperature $\left(50^{\circ} \mathrm{C}\right)$, and butter oil concentration (10 wt\%). Our results are in agreement with previous reports in that, if the presence of a single surfactant results in a dramatic lowering of the size of the fat globules, the near absence of surfactants $\left([\text { Prot }]_{\min }=0.5 \mathrm{wt} \%\right.$, and $[M G S]_{\min }=0.08$ wt\%) results in a maximum value for $\bar{d}_{v}$ $(678 \mathrm{~nm})$.

\section{Relative width of the size distribution of the emulsified fat globules}

A preliminary statistical analysis has revealed that the variations of $c v$ as a function of various independent variables could not be adequately described by a secondorder model ( $r^{2}=0.71$ after pooling; the adjustment test was not significant) in the original validity interval. A reduction of the 


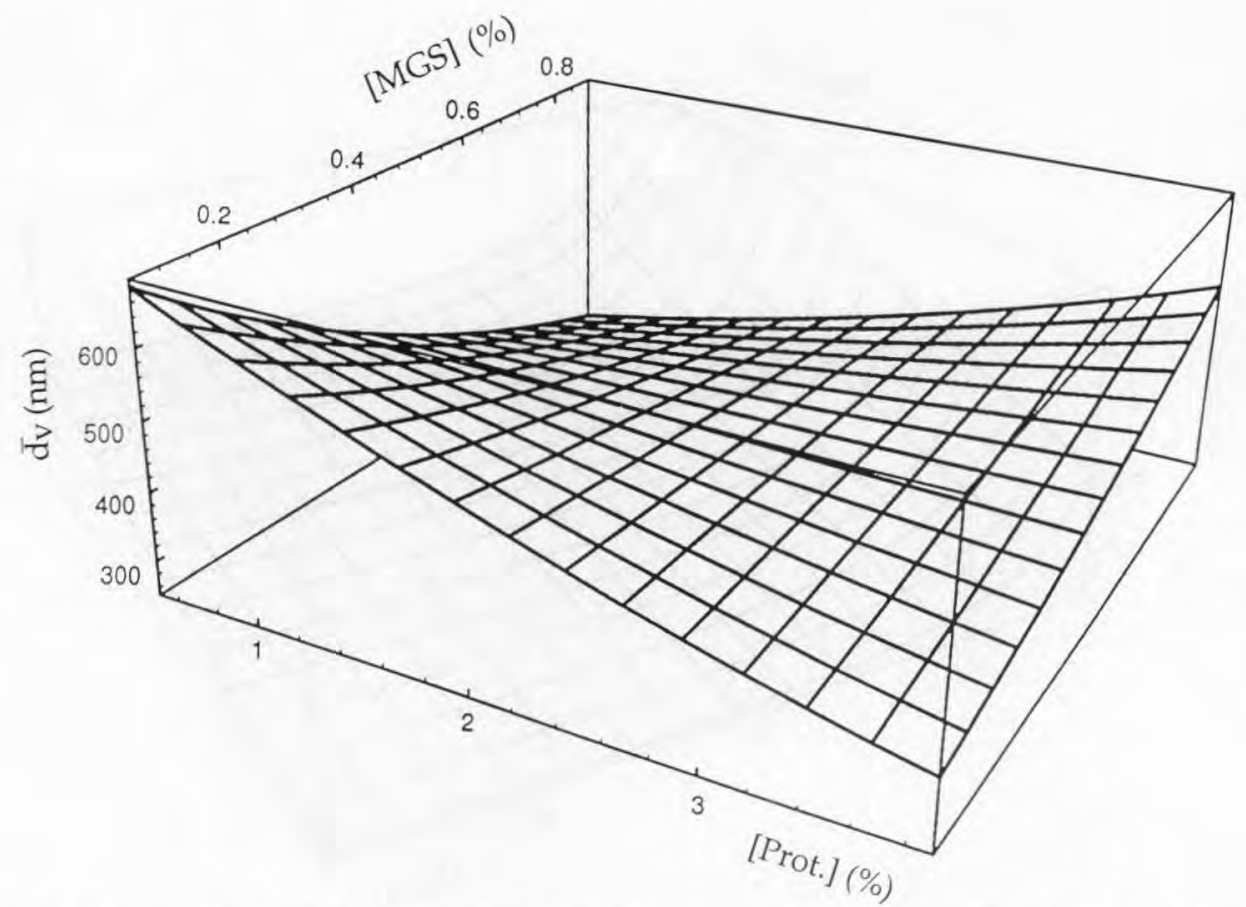

Fig 2. Response surface of the volume-weighted average fat globule diameter as a function of protein, $[$ Prof] $(w t \%)$, and monoglyceride, [MGS] (wt\%), concentrations for a fixed temperature ( $T=$ $\left.50^{\circ} \mathrm{C}\right)$, a fixed pressure $(P=50 \mathrm{MPa})$, and butter oil concentration $\left.[B O]=10 \mathrm{wt} \%\right)$.

Surface de réponse du diamètre moyen pondéré en volume des globules de gras en fonction des concentrations en protéines, [Prot] (\%), et monoglycérides, [MGS] (\%), pour une température $(T=$ $\left.50^{\circ} \mathrm{C}\right)$, une pression $(\mathrm{P}=50 \mathrm{MPa})$, et une concentration en huile de beurre $([\mathrm{BO}]=10 \%)$ fixées.

interval corresponding to the elimination of an extreme point (No 49) has consequently been effected.

Table IV shows the analysis of variance of $c v$ as a function of the process variables. According to the adjustment test, for $p \leq 0.01$ ( $F<4.77$ ), a second-order model could adequately describe the variances of $c v$ in this new validity interval. As mentioned previously, the linear effects of the principal factors, except the temperature one, were significant (from $95 \%$ to $99.999 \%$ ). The protein and monoglyceride concentrations had an important effect on the variance of $\mathrm{cr}$. they explained respec- tively $16.0 \%$ and $13.4 \%$ of the total variance. The emulsification pressure and temperature represented respectively $16.8 \%$ and $2.7 \%$ (the sum of the linear and quadratic effects: $P+P^{2}$ and $T^{2}$ ) of the variance of $c v$. The effect of the butter oil concentration ( $p \leq 0.0001$ ) represented $7.7 \%$ of the variance of $c v$. The other highly significant interactions ([Prof $] \times[B O]$ and $[B O] \times P$ ) represented $28.5 \%$ of the total variance. The error represented approximately $10.2 \%$ of the variance of $c v$.

$A$ regression equation, calculated using highly significant effects ( $p \leq 0.0001)$ from the analysis of variance of $c v$, is shown in 


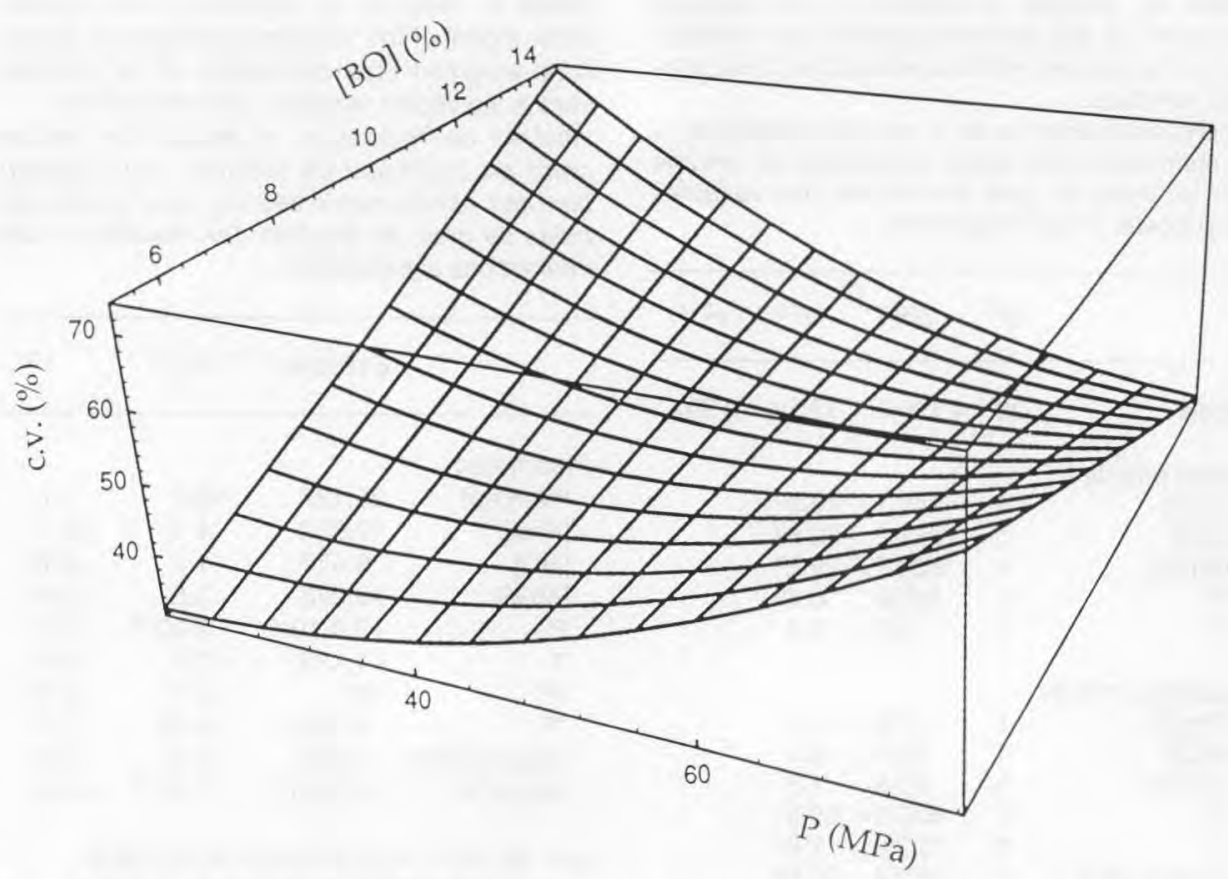

Fig 3. Response surface of the coefficient of variation standard of the volume-weighted size distribution of fat globules as a function of emulsification pressure, $P(\mathrm{MPa})$, and butter oil concentration, $[B O](w t \%)$, for a fixed temperature $\left(T=50^{\circ} \mathrm{C}\right)$, a fixed protein concentration ( $[$ Prof $\left.]=1.5 \mathrm{wt} \%\right)$, and a fixed monoglyceride concentration ([MGS] $=0.4 \mathrm{wt} \%$ ).

Surface de réponse du coefficient de variation de la distribution des tailles pondérées en volume des globules de gras en fonction de la pression d'émulsification, $\mathrm{P}(\mathrm{MPa})$, et de la concentration en huile de beurre, $[\mathrm{BO}](\%)$, pour une température donnée $\left(T=50^{\circ} \mathrm{C}\right)$, et des concentrations fixées en protéines ([Prot $]=1.5 \%$ ) et en monoglycérides ([MGS $]=0.4 \%$ ).

$\left(T=50^{\circ} \mathrm{C}\right)$, a fixed protein concentration $([$ Prot $]=1.5 \mathrm{wt} \%)$, and a fixed monoglyceride concentration ([MGS] $=0.4$ $w t \%)$. An increase in the emulsification pressure and/or butter oil concentration resulted in an increase in the value of $\mathrm{cv}$. This figure also shows the minimal values for $c v$ that are a function of both $P$ and [BO] (table IV).

Figure 4 shows the response surface obtained from a second-order model of the volume-weighted size distribution of fat globules as a function of protein and monoglyceride concentration, for a fixed temperature $\left(50^{\circ} \mathrm{C}\right)$, pressure $(50 \mathrm{MPa})$ and butter oil concentration (10 wt\%). This figure indicates the cooperative effect of surfactant content on the reduction in $\mathrm{cv}$ of this volume-weighted distribution.

\section{$\mathrm{pH}$ of the emulsions}

The average $\mathrm{pH}$ of the 52 emulsions was 7.06 with a standard deviation of \pm 0.04 . All emulsions therefore had similar acid/base properties. 


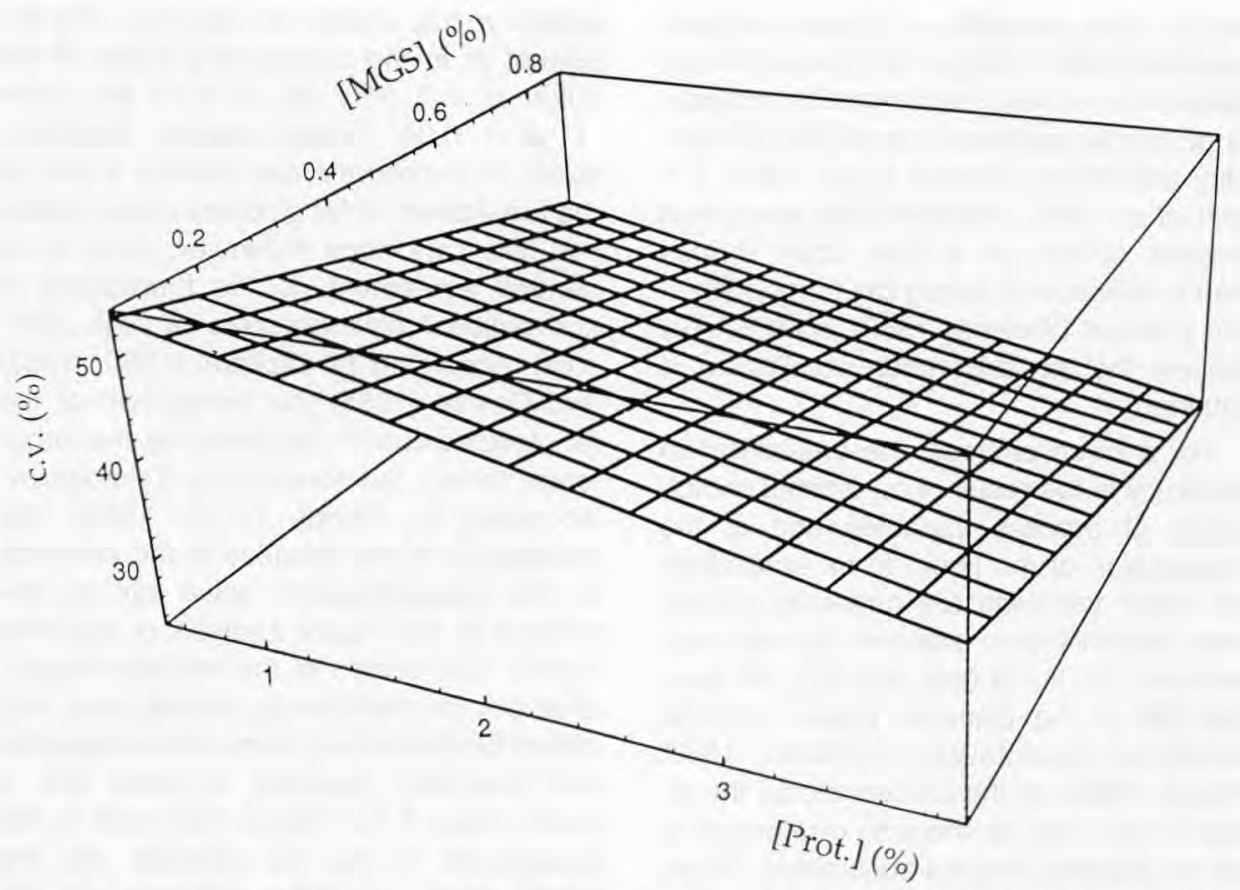

Fig 4. Response surface of the coefficient of variation of the volume-weighted size distribution of fat globules as a function of protein, [Prof] $(w t \%)$, and monglyceride, [MGS] (wt\%), concentrations for a fixed temperature $\left(T=50^{\circ} \mathrm{C}\right)$, a fixed pressure $(P=50 \mathrm{MPa})$, and butter oil concentration $([B O]=10$ wt\%).

Surface de réponse du coefficient de variation de la distribution des tailles pondérées en volume des globules de gras en fonction des concentration en protéines, [Prot] (\%), et monoglycérides, [MGS] (\%), pour une température $\left(T=50^{\circ} \mathrm{C}\right)$, une pression $(\mathrm{P}=50 \mathrm{MPa})$, et une concentration en huile de beurre $([\mathrm{BO}]=10 \%)$ fixées.

\section{DISCUSSION}

Emulsification is a dynamic process where the disruption and recombination or coalescence of the fat globules take place simultaneously, each with its own rate constant or time scale (Walstra, 1983; Tornberg et al, 1990). Consequently, not only the final droplet size distribution but also other emulsion properties such as rheological behavior will be determined by the conditions leading to an equilibrium between breakdown and coalescence. The probability of newly formed droplets coalescing depends on the time available for the interfaces to be covered by the surfactants. The time available depends on emulsifying conditions (eg emulsifying machine, power density), which are influenced by the fat content, the ratio of surfactant to fat, and the nature of the surfactants. In order to be active (prevent coalescence), surfactants must not only be transported to the interfaces, they must also be able to adsorb. Adsorption depends on the number of surfactant collisions with fat particles, 
and on the probability of the surfactants adsorbing after colliding with the interface. Adsorption is likely influenced by molecular properties such as hydrophobicity, flexibility and charge density (Kato, 1991; Lorient et al, 1991). However, the adsorption process occurs on a time scale of less than a millisecond during the homogenization process (Walstra, 1983), so it is very unlikely that an adsorption equilibrium is obtained.

For a given process, the emulsification efficiency is the result of an optimal combination of process variables and of the composition of the liquid to be emulsified. Six major variables are generally considered: emulsification pressure $(P)$ and temperature $(T)$, liquid flow rate $(Q)$, the fraction $(\Phi)$ of the disperse phase and the surfactant concentration(s) (Walstra, 1983; Phipps, 1985). In the present study, the effect of flow rate on the size distribution of the fat globules was not considered. It has, however, been shown for oil-in-water emulsions (Phipps, 1975, 1982, 1983; Walstra, 1975) and for conventional homogenizers (Manton-Gaulin and/or Rannie), that there is little or no influence of the flow rate of the liquid to be emulsified when $\Phi \leq 30 \%$.

\section{Influence of process variables on the size distribution of fat globules}

\section{Effect of emulsification pressure}

It was empirically shown (Goulden and Phipps, 1964; among others) and then vindicated by Walstra $(1969,1975)$ that classic homogenization processes (the systems of Manton-Gaulin or Rannie), at moderate emulsification pressures $(0.25$ $\mathrm{MPa} \leq P \leq 40.5 \mathrm{MPa}$ ), using milk, cream with a fat concentration of $\Phi \leq 12 \%$ or any other dilute emulsion, could be quantified by a relation such as $d \propto P^{m}$ where the ex- ponent $m$ has a value of $-3 / 5$ ([1]). The exponent $m$ in the descending slope of the curve $\bar{d}_{v}=f(P m)$ (fig 1$)$ is of the order $-0.53 \pm 0.04$. These results, therefore, seem to corroborate the theories linked to the breakdown of fat globules during turbulent flow conditions. However, there is no general agreement on the functioning of conventional homogenizers at high pressure. According to Walstra $(1969,1983)$ and Davies (1985) the breakdown of the fat globules can be described by the turbulence theory put forward by Kolmogorov. According to Phipps $(1975,1985)$, the breakdown of the globules at the entrance to the homogenization valve can be described by the Taylor analysis of shearing forces. The design of the microfluidization chamber (microchannels, mixing zone, etc) differs fundamentally from an homogenization chamber (basically a valve and a seat). Even if the forces that lead to the breakdown of the fat globules are the same, their respective influence on the breakdown is apparently not the same.

Although the convex nature of the curve $\bar{d}_{v}=f(P)_{[B O]}$ (fig 1) is the result of an experimental artefact and of its statistical consequence (the minimum is very shallow), some authors (Becher, 1967; Phipps, 1975; Tornberg, 1980) have reported that an increase in homogenization intensity $(E)$, and/or fat concentration above optimal yields ( $P \geq 40 \mathrm{MPa}$ or $E \geq 60 \mathrm{~W}$ and/or $\Phi \geq$ $12 \%)$ could result in an increase in droplet size. This increase, called overprocessing by Tornberg (1980), should indicate that coalescence is the dominant factor governing the final droplet size of the emulsion. However, the validity of the methods that have been used for producing emulsions and determining average size is questionable. In the present study, it is reasonable to think that an increase in collision frequency with increasing pressure would at most lead to no further decrease in globule size as the minimum is very shallow. An in- 
crease in emulsification intensity above optimal conditions, which causes a relatively small change in average droplet size, results in unnecessary energy consumption. The optimal condition corresponded to $P \cong$ $50 \mathrm{MPa}$. The reduction in fat globule size have various consequences. Emulsions which contain small droplets have a tendency to be more stable with respect to creaming (Stokes' law), and to coalesce more than those containing large droplets (MacRitchie, 1976). According to the MacRitchie approach, which correlates film stability to an energy barrier, the compressional free energy barrier can be, under some conditions, proportional to $1 / d^{R}$. However, in practice the effects are not as great as predicted by these equations (Walstra and Oortwijn, 1975; Dickinson and Stainsby, 1982).

If the average particle size can provide some information about the behavior of emulsions, most attention should, however, be paid to the top end of the size distribution as most types of instability are usually first manifested by the behavior of the largest droplets. Although the distribution width of fat globules is an extremely important parameter when characterizing an emulsion, it has not been studied in great depth. Walstra (1975) demonstrated that the relative width of fat globules in homogenized milk sharply increases with the homogenization pressure $(0<P<5 \mathrm{MPa})$, reaches a maximum $(P \cong 5 \mathrm{MPa})$ before remaining fairly constant and attaining a limit $(P \cong 30 \mathrm{MPa})$. These results were partly confirmed by Tornberg (1980) studying the behavior of various protein stabilized emulsions made by a sonifier. In the present study, valid for $20.4 \mathrm{MPa} \leq P \leq$ 76.3 $\mathrm{MPa}$, the results revealed a behavior that differed as a function of butter oil concentration $([B O]$, wt\%). At quite high $[B O]$, in conformity with previously mentioned results, the relative width of the fat globule distribution diminished as a function of emulsification pressure. However, at lower concentrations, the behavior was reversed. Although these trends should be interpreted with some caution (lack of accuracy in the determination of the standard deviation, low $r^{2}$ value), it appears that trends near central points are similar to those reported elsewhere. At the endpoints of the experimental design, trends are much more difficult to establish, particularly when the decrease in $\mathrm{cv}$ as a function of $[\mathrm{BO}]$ at high $P$ should arise from the standard deviation(s) being less affected than $\bar{d}_{v}$ by the emulsification intensity.

\section{Effect of emulsification temperature}

Since Gaulin, it has been recognized that the efficiency of the emulsification process is very low in the presence of solid fat (Kessler, 1981). Consequently, the production of oil-in-water emulsions is normally carried out at temperatures above the final melting temperature of the fat $\left(T_{f} \cong 40^{\circ} \mathrm{C}\right.$, Jenness and Walstra, 1984). Several authors, studying the homogenization of milk, have shown that an increase of $10^{\circ} \mathrm{C}$ in temperature between $40-70{ }^{\circ} \mathrm{C}$ decreases the average diameter of the fat globules by $6-8 \%$ (Walstra, 1975 ) to $10-15 \%$ (Sweetsur and Muir, 1983). This effect weakens or disappears above $80^{\circ} \mathrm{C}$. As expected, an increase in temperature between $35-82{ }^{\circ} \mathrm{C}$ resulted in a decrease in the average diameter of $\approx 8 \% / 10^{\circ} \mathrm{C}$. Although equation [1] does not predict that the viscosity of either phase can have an effect on the droplet size resulting from the emulsification process in turbulent flow, a decrease of viscosity will understandably affect the rate of passage through the emulsifier and the ease of disruption of the globules. Walstra $(1974,1983)$ suggested that an increase in the viscosity of the dispersed phase $\left(\eta_{D}\right)$ should correspond to a deformation time of a droplet larger than the character- 
istic time of an eddy. As the smallest eddies are presumably the most effective (they have the highest kinetic energy), an increase in $\eta_{D}$ should lead to a larger spread in flow conditions and consequently in droplet size distribution (cv), as was indeed the case. Moreover, an increase in temperature changes all the composition variables that determine adsorption; fat changes to oil and the macromolecular penetration into the oil becomes possible, hydrophobic interactions at the interface probably become more intense (at least up to $60-65^{\circ} \mathrm{C}$ ), and the molecular structure of water weakens, which affects its quality as a solvent for surfactants and for hydrophobic interactions. Above $82^{\circ} \mathrm{C}$, the average particle diameter increased slightly. Although this result has not been explained, it should be noted that the influence of the temperature on the average diameter of the fat globules is relatively low: temperature only explains $4.8 \%$ (table II) of the total variance of $\log _{10}\left(\bar{d}_{v}\right)$ and between 82 and $100{ }^{\circ} \mathrm{C}$ it represents $<1 \%$ which is much lower than the experimental error $(\approx 6.3 \%)$. Moreover, the statistical increase in $\bar{d}_{v}$ is a consequence of the measurements obtained from an emulsion that was not repeated (No $=48$ ) and corresponds to an extreme point (star point) in the experimental design. $c v$ was influenced in a similar manner by the temperature (table V).

\section{Effect of composition variables on the size distribution of fat globules}

\section{Effect of butter oil concentration}

The concentration of fat affects the homogenization efficiency of dairy products when it is > 10\% (Walstra, 1975; Phipps, 1985). The microfluidization of the model emulsion demonstrated that an increase in the butter oil concentration $(5.2 \leq[B O] \leq 14$ $w t \%)$ resulted in a very significant increase in the average diameter of the fat globules $\left(\bar{d}_{v}\right)$ (table II, fig 1) and in the size distribution (cv at low pressure) (table III, fig 3). An increase in the fat concentration resulted in a relative decrease in the concentration of surfactant available to cover the new interfacial surface that was formed during the emulsification process. The fat content and the ratio of surfactants to fat affected the extent of coalescence of the newly formed globules by governing the probability that the latter collide before they recover by a surfactant layer. Also, with higher oil concentrations, distances between fat globules decrease and the probability of bridging could increase. This results in a general tendency to increase "particle" diameter.

\section{Effect of surfactant concentration}

The addition of surfactants, which results in a decrease in interfacial tension $(\gamma)$, reduces the interfacial free energy $(\Delta G)$ of the system,

$$
\Delta G=\gamma \Delta S
$$

where $\Delta S$ is the change in the interfacial area

and thereby the Laplace pressure which is beneficial in reducing both the energy requirement to form emulsions and the droplet size that can be obtained. However, this only holds if the ratio (surfactant/interfacial surface) is large enough to cover the new interfacial surface formed during the emulsification process and leading to minimize the coalescence or polymeric bridging (Halling, 1981; Tadros and Vincent, 1983). For minimal protein and monoglyceride concentrations $([$ Prof $]=0.5 w t \%,[M G S]=$ 0.08 wt $\%$, with $P=50 \mathrm{MPa}, T=50^{\circ} \mathrm{C}$, $[B O]=10 w t \%)$, the average diameter of the fat globules was at a maximum $\left(\bar{d}_{v}=\right.$ $678 \mathrm{~nm})$. 
Although certain general rules can be deduced from simple thermodynamic principles, the degree and, more importantly, the consequences of the adsorption of protein to the interface can vary considerably with the type of protein and with emulsification conditions. Thus, while Oortwijn and Walstra (1979) reported that whey protein concentration $(0.01-2.0 \%)$ had relatively little effect on the size of fat globules in homogenized emulsions, Pearce and Kinsella (1978) demonstrated, using homogenized emulsions stabilized with various proteins, that increasing the protein concentration $(0.5-5 \%)$ could decrease the average diameter of the fat globules by a factor of 2.5. Thus, the nature of the surfactant (hydrophile-lipophile balance, molecular weight, molecular flexibility) as well as its relative concentration (with respect to other surfactants) directly influence the size of the fat globules. Figure 2 illustrates the complex influences of the chemical structure and of protein and monoglyceride concentration on the average diameter of emulsified fat globules; the other variables were kept constant $\left(P=50 \mathrm{MPa}, T=50^{\circ} \mathrm{C},[B O]=10 \mathrm{wt} \%\right)$. During the emulsification process, smaller droplets $\left(\bar{d}_{v}=259 \mathrm{~nm}\right)$ are produced in the presence of low concentrations of proteins and high concentrations of monoglycerides $([$ Prot $]=0.5 \mathrm{wt} \%$ and $[$ MGS $]=$ 0.88 wt $\%$, respectively) because monoglycerides are better able to lower interfacial tension than proteins alone. With high protein concentrations and low monoglyceride concentrations, $\bar{d}_{v}=350 \mathrm{~nm}$. Dickinson et al (1989) reported similar trends when studying the effect of octaoxyethylene dodecyl ether $\left(C_{12} E_{8}\right)$ with 0.1 wt $\%$ caseinate on the droplet diameter of ON emulsion (20 wt\% n-tetradecane, $\mathrm{pH} 7$, $25^{\circ} \mathrm{C}$ ). However, care is needed when analysing these results as the surfactants used were different and hydrocarbons have a higher interfacial tension with wa- ter than do mixtures of triglycerides with water (Fisher et al, 1985).

Moreover, the increase in the concentration of surfactant (for a given [BO], $P$ and $T$ results in a decrease in the average particle diameter (Dickinson et al, 1989) if the monoglycerides to protein ratio is lower or equal to 0.15 , eg $[$ Prot $]=2.85 w t \%$ and $[M G S]=0.46 w t \%$ (fig 2). Although these concentrations are independent of the $[B O]$, which is rather surprising, it is suggested that an increase in the size of the fat globules above these concentrations can be attributed to,

- a competition between fat and monoglycerides to bind proteins due to the high number of monoglyceride molecules per residue of caseinate and to the formation of hydrophobic bonds between a polar amino acids and the hydrocarbon groups of the monoglycerides (Dickinson and Woskett, 1989). These weak complexes, if they form, should be rather surface-inactive, as the hydrophobic areas of protein and nonionic surfactant bind together, and

- to protein displacement from the interface by monoglycerides. In another study using casein and MGS, Paquin et al (1987) found that surface pressure isotherms in the high-pressure region are essentially the same as for the monoglycerides alone, suggesting protein displacement from the interface. It is likely, as suggested by Doxastakis and Sherman (1986), that mono- and diglycerides present in commercial glycerol monostearate form complexes with caseinate at the oil-water interface. It would appear that this (mixed) emulsifier does not behave simply as a nonionic, noninteracting surfactant.

Surfactants (proteins and low molecular weight surfactants) seem to have a cooperative effect on the reduction of $c v$ (fig 4). As was mentioned in the discussion on the determination of $\mathrm{cv}$, these results must be interpreted with caution. 

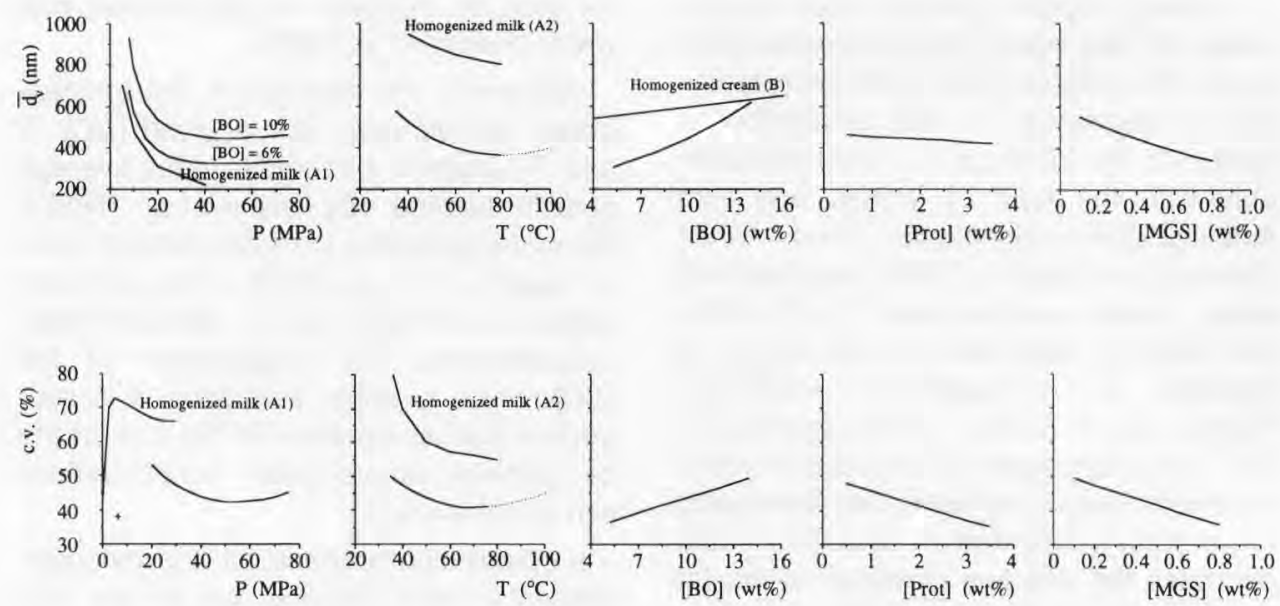

Fig 5. Effect of process and composition variables on fat globule size distribution parameters. For each graph, values of 4 variables were either fixed or specified. Values of fixed variables were: $P=50$ $\mathrm{MPa}, T=50^{\circ} \mathrm{C},[B O]=10 \mathrm{wt} \%,[$ Prot $]=1.5 \mathrm{wt} \%,[M G S]=0.4 \mathrm{wt} \%$.

Effets des variables de procédés et de composition sur les paramètres de la distribution des tailles des globules de gras. Pour chaque figure, les valeurs des 4 variables étaient soit fixées soit spécificiées. Lorsque les variables étaient fixées, leur valeur était : $\mathrm{P}=50 \mathrm{MPa}, \mathrm{T}=50^{\circ} \mathrm{C},[\mathrm{BO}]=10 \%$, [Prot $]=1.5 \%$, MGS $]=0.4 \%$.

(A): Walstra. 1975; $A_{1}, p$ 282; $A_{2}, p$ 289. (B): Phipps, 1985, p 12.

\section{CONCLUSIONS}

The process and composition variables which were studied affect, in varying proportions, the efficiency of the emulsification process called microfluidization. Some of these influences are summarized in figure 5 . The variables that had the greatest influence on the size distribution of the fat globules are the butter oil concentration, the concentration of low molecular weight surfactants (monoglycerides), the emulsification pressure, the protein concentration (sodium caseinates) and the emulsification temperature. However, if the average sizes are fairly reliable, the results on relative distribution width must be taken with caution.
The utilization of an experimental design, applied to a dairy-type emulsion, demonstrated the complexity of the influences and interactions (depending on the area of study, pressure, temperature or concentrations) of process and composition variables on the size distribution of the fat globules. If the usefuiness of mechanistic and thermodynamic principles is not in doubt, it is still impossible to completely predict all aspects of the behavior of an emulsion.

Finally, although this work was carried out on a model system and although it was demonstrated that for other conditions (the existence of interaction terms) the effects would be different, the results should pro- 
vide a guide for optimizing the emulsification process.

\section{ACKNOWLEDGMENTS}

We are indebted to the first reviewer for his helpful comments.

\section{REFERENCES}

Bargeron CB (1974) Analysis of intensity correlation spectra of mixtures of polystyrene latex spheres: a comparison of direct least squares fitting with the method of cumulants. $J$ Chem Phys 60, 2516-2519

Becher P (1967) Effect of preparation parameters on the initial size distribution functions in oil-in-water emulsions. J Colloid Interface Sci 24, 91-96

Box GE, Drapper NR (1987) Empirical Model Building and Response Surfaces. John Wiley and Sons, NY

Brown JC, Pusey PN (1975) Photon correlation study on the initial size distribution function in oil-in-water emulsions. J Chem Phys 62, 1136-1144

Chandonnet S, Korstvedt $\mathrm{H}$, Siciliano AA (1985) Preparation of microemulsions by microfluidization. Soap Cosmet Chem Spec (Feb) 3738

Cook EJ, Lagace AP (1985) Apparatus for forming emulsions. US Pat 4533254

Chu B, Dinapoli A (1983) Extraction of distributions of decay times in photon correlation of polydisperse macromolecular solutions. In: Measurement of Suspended Particles by Quasi-Elastic Light Scattering (Dahneke BE, ed) John Wiley and Sons, NY, 81-105

Dalgleish DG, Pouliot Y, Paquin P (1987) Studies on heat stability of milk. II. Association and dissociation of particles and the effect of added urea. J Dairy Res 54, 39-49

Darling DF, Birkett RJ (1987) Food colloids in practice. In: Food Emulsions and Foams (Dickinson E, ed) R Soc Chem, London, 1-29

Davies JT (1985) Drop sizes of emulsions related to turbulent energy dissipation rates. Chem Eng Sci 40, 839-842
Dickinson E (1986) Mixed proteinaceous emulsifiers: review of competitive protein adsorption and the relationship to food colloid stabilization. Food Hydrocol 1, 3-23

Dickinson E, Stainsby G (1982) Food Colloids. Elsevier Appl Sci Publ, London

Dickinson E, Stainsby G (1988) Emulsion stability. In: Advances in Food Emulsions and Foams (Dickinson E, Stainsby G, eds) Elsevier Appl Sci Publ, London, 1-44

Dickinson E, Woskett CM (1989) Competitive adsorption between proteins and smallmolecule surfactants in food emulsions. In: Food Colloids (Bee RD, Richmond P, Mingins J, eds) R Soc Chem, London, 74-96

Dickinson E, Mauffret A, Rolfe SE, Woskett CM (1989) Adsorption at interfaces in dairy systems. J Soc Dairy Technol 42, 18-22

Dickinson E, Euston SR, Woskett CM (1990) Competitive adsorption of food macromolecules and surfactants at the oil-water interface. Prog Colloid Polym Sci 82, 65-75

Doxatakis G, Sherman P (1986) The interaction of sodium caseinate with monoglyceride and diglyceride at the oil-water interface and its effect on interfacial rheological properties. Colloid Polym Sci 264, 254-259

Fisher LR, Parker NS (1988) Effect of surfactants on the interactions between emulsion droplets. In: Advances in Food Emulsions and Foams (Dickinson E, Stainsby G, eds) Elsevier Appl Sci Publ, London, 45-90

Fisher LR, Mitchell EE, Parker NS (1985) Interfacial tensions of commercial vegetable oils with water. J Food Sci 50, 1201-1202

Gacula MC, Singh J (1984) Statistical Methods in Food and Consumer Research. Food Science and Technology. Academic Press, NY, 214-272

Goulden JDS, Phipps LW (1964) Factors affecting the fat globule size during the homogenization of milk and cream. $J$ Dairy Sci 31 , 195-200

Halling PJ (1981) Protein-stabilized foams and emulsions. CRC Crit Rev Food Sci Nutr 13, 155-203

Jenness R, Walstra P (1984) Dairy Chemistry and Physics. John Wiley and Sons, NY, 8889 
Kato A (1991) Significance of macromolecular interaction and stability in functional properties of food proteins. In: Interaction of Food Proteins (Parris N, Barford R, eds) ACS Symp Ser 454, Am Chem Soc, Washington, DC, 13-24

Kessler HG (1981) Food Engineering and Dairy Technology. Verlag A Kessler, Freising, 119138

Koppel DE (1972) Analysis of macromolecular polydispersity in intensity correlation spectroscopy: the method of cumulants. $J$ Chem Phys 57, 4814-4820

Little TM (1981) Interpretation and presentation of results. Hortic Sci 16, 19-31

Lorient D, Closs B, Courthaudon JL (1991) Connaissances nouvelles sur les propriétés fonctionnelles des protéines du lait et de ses dérivés. Lait 71, 141-171

MacRitchie F (1976) Monolayer compression barrier in emulsion and foam stability. $J \mathrm{Col}$ loid Interface Sci 56, 53-56

Montgomery DC (1976) Design and Analysis of Experiments. John Wiley and Sons, NY, 341-368

Neter J, Wasserman W, Kutner M (1985) Applied Linear Statistical Models: Regression, Analysis of Variance and Experimental Designs. Irwin, Homewood, 2nd edn

Ogden LV (1973) The homogenization-induced clustering of fat globules in cream and model systems. Ph Dissertation, Univ Minnesota, St Paul, MN

Oorwijn H, Walstra P (1979) The membranes of recombined fat globules. 2. Composition. Neth Milk Dairy J 33, 134-154

Paquin $\mathrm{P}$, Britten $\mathrm{M}$, Laliberté MF, Boulet M (1987) Interfacial properties of milk casein proteins. In: Proteins at Interfaces: Physicochemical and Biochemical Studies (Brash JL, Horbett TA, eds) ACS Symp Ser 343, Washington DC, 677-686

Paquin P, Giasson J (1989) La microfluidisation comme procédé d'homogénéisation d'une boisson à base de matière grasse laitière. Lait 69, 491-498

Pearce KN, Kinsella JE (1978) Emulsifying properties of proteins: evaluation of a turbidimetric technique. J Agric Food Chem 26, 716-723
Phipps LW (1975) The fragmentation of oil drops in emulsions by high-pressure homogenizer. J Phys D: Appl Phys 8, 448-462

Phipps LW (1982) Homogenizing valve design and its influence on milk fat globule dispersion. I. Low rate of flow (100 I.h-1 Re $\leq$ 3000). J Dairy Res 49, 309-315

Phipps LW (1983) Effects of fat concentration on the homogenization of cream. J Dairy Res $50,91-96$

Phipps LW (1985) The High Pressure Dairy Homogenizer. Tech Bull 6. Nat Inst Res Dairying, Reading, UK

Piggott JR (1986) Statistical Procedures in Food Research. Elsevier Appl Sci Publ, London, 101-123

Pouliot Y, Paquin P, Robin O, Giasson J (1991) Étude comparative de l'effet de la microfluidisation et de l'homogénéisation sur la distribution de la taille des globules de gras du lait de vache. Int Dairy J.1, 39-49

Robin O, Paquin P (1991) Evaluation of the particle size of fat globules in a milk model emulsion by photon correlation spectroscopy. $J$ Dairy Sci 74, 2440-2447

SAS® (1990) SAS User's Guide: statistics Version 6.06. SAS Inst Inc, Cary, NC

Shinoda K, Kunieda H (1983) Phase properties of emulsions: PIT and HLB. In Encyclopedia of Emulsion Technology. 1. Basic Theory (Becher P, ed) Marcel Dekker, NY, 337-367

Sweetsur MA, Muir DD (1983) Effect of homogenization on the heat stability of milk. $J$ Dairy Res 50, 291-300

Tadros TF, Vincent B (1983) Emulsion stability. In: Encyclopedia of Emulsion Technology. 1. Basic Theory (Becher P, ed) Marcel Dekker, NY, 129-285

Tornberg E (1980) Functional characteristics of protein stabilized emulsions: emulsifying behavior of proteins in a sonifier. J Food Sci 45, 1662-1668

Tornberg E, Olson A, Persson K (1990) Structural and interfacial properties of food proteins in relation to their function in emulsions. In: Food Emulsions (Larsson K, Friberg SE, eds) Marcel Dekker, NY, 247-326

Vuillemard JC (1991) Recent advances in the large scale production of lipid vesicles for use 
in food products: microfluidization. $J$ Microencapsul 8, 547-562

Walstra P (1969) Preliminary note on the mechanism of homogenization. Neth Milk Dairy $J$ 23, 290-292

Walstra P (1974) Influence of rheological properties of both phases on droplet size of ON emulsions obtained by homogenization and similar processes. Dechema Monogr 77, 8794

Walstra P (1975) Effect of homogenization on the fat globule size distribution in milk. Neth Milk Dairy J 29, 279-294

Walstra P (1983) Emulsion formation. In: Encyclopedia of Emulsion Technology. 1. Basic Theory (Becher P, ed) Marcel Dekker, NY, 57-127
Walstra P, Oortwijn H (1982) The membranes of recombined fat globules. 3. Mode of formation. Neth Milk Dairy J 36, 103-113

Washington C (1987) Emulsion production by microfluidizer. Lab Equip Dig 85, 69-71

Weiner BB, Tscharnuter WW (1987) Uses and abuses of photon correlation spectroscopy in particle sizing. In: Particle Size Distribution: Assessment and Characterization (Provder T, ed) ACS Symp Ser 332, Am Chem Soc, Washington DC, 48-64

Wolfram S (1991) Mathematica: A System for Doing Mathematics by Computer. AddisonWesley Publ Co Inc, Champaign, IL, 2nd edn 